\title{
Hypercapnia-Induced Modifications of Neuronal Function in the Cerebral Cortex of Newborn Piglets
}

\author{
KAREN I. FRITZ, ALAN ZUBROW, OM P. MISHRA, AND MARIA DELIVORIA-PAPADOPOULOS \\ Department of Pediatrics, Drexel University College of Medicine and St. Christopher's Hospital for \\ Children, Philadelphia, Pennsylvania 19134
}

\begin{tabular}{|c|c|}
\hline \multicolumn{2}{|c|}{ ABSTRACT } \\
\hline $\begin{array}{l}\text { There is significant controversy over the effects of hypercap- } \\
\text { nia on the human newborn brain. Previous studies have shown } \\
\text { that } 1 \mathrm{~h} \text { of an arterial } \mathrm{CO}_{2} \text { pressure }\left(\mathrm{PaCO}_{2}\right) \text { of } 80 \mathrm{~mm} \mathrm{Hg} \text { alters } \\
\text { brain cell membrane } \mathrm{Na}^{+} \mathrm{K}^{+} \text {-ATPase enzyme activity in the } \\
\text { cerebral cortex of newborn piglets. The present study tests the } \\
\text { hypothesis that hypercapnia (either a } \mathrm{PaCO}_{2} \text { of } 65 \text { or } 80 \mathrm{~mm} \mathrm{Hg} \text { ) } \\
\text { results in decreased energy metabolism and alters neuronal nu- } \\
\text { clear enzyme activity and protein expression, specifically Ca }{ }^{++} \text {/ } \\
\text { calmodulin-dependent kinase (CaMK) IV activity, phosphoryla- } \\
\text { tion of cAMP response element binding protein (CREB), and } \\
\text { expression of apoptotic proteins in cortical neuronal nuclei of } \\
\text { newborn piglets. Studies were performed in } 20 \text { anesthetized } \\
\text { normoxic piglets ventilated at either a Paco of } 65 \text { mm Hg, } 80 \\
\text { mm Hg, or } 40 \text { mm Hg for } 6 \text { h. Energy metabolism was docu- } \\
\text { mented by ATP and phosphocreatine (PCr) levels. Results show } \\
\text { ATP and PCr levels were significantly lower in the hypercapnic } \\
\text { groups than the normocapnic. CaMK IV activity, phosphorylated } \\
\text { CREB density, and Bax protein expression were all significantly }\end{array}$ & $\begin{array}{l}\text { higher in the hypercapnic groups than the normocapnic group. } \\
\text { Bcl-2 protein was similar in all three groups, making the ratio of } \\
\text { Bax/Bcl-2 significantly higher in the hypercapnic groups than in } \\
\text { the normocapnic group. We conclude that hypercapnia alters } \\
\text { neuronal energy metabolism, increases phosphorylation of tran- } \\
\text { scription factors, and increases the expression of apoptotic pro- } \\
\text { teins in the cerebral cortex of newborn piglets and therefore may } \\
\text { be deleterious to the newborn brain. (Pediatr Res 57: 299-304, } \\
\text { 2005) } \\
\text { Abbreviations } \\
\text { CaMK IV, Ca }{ }^{++} / \text {calmodulin-dependent kinase IV } \\
\text { CBF, cerebral blood flow } \\
\text { CREB, cAMP response element binding protein } \\
\text { NMDA, } N \text {-methyl-D-aspartate } \\
\text { PCr, phosphocreatine } \\
\text { pH } \text {, extracellular pH } \\
\text { pH } \text {, intracellular pH }\end{array}$ \\
\hline
\end{tabular}

The long-term neurologic morbidity for preterm and ill term human newborns remains a serious concern. Among these infants, hypercapnia is a common occurrence. Current clinical practice often allows infants ventilated acutely or chronically to remain hypercapnic (undergoing "permissive hypercapnia") to limit ventilator-induced lung injury. The effects of hypercapnia on the newborn brain are controversial as there is not a known safe range of arterial $\mathrm{CO}_{2}$ pressure $\left(\mathrm{PaCO}_{2}\right)$.

Some recent clinical studies have not shown an immediate harmful effect of hypercapnia in human infants (1-3). However, in most of these studies, long-term neurologic outcomes were not reported. In addition, subtle alterations in brain

Received September 3, 2003; accepted July 22, 2004

Correspondence: Karen I. Fritz, M.D., Department of Pediatrics, Drexel University College of Medicine, St. Christopher's Hospital for Children, Division of Neonatology, Front and Erie Sts., Ste. 2212, Philadelphia, PA 19134; e-mail: Karen.I.Fritz@Drexel.edu

Supported by grants from the National Institutes of Health (NIH-HD 20337 and NIH-HD 38079) and St. Christopher's Foundation.

DOI: 10.1203/01.PDR.0000148718.47137.9B structure and function may not be detectable in these clinical studies.

Hypercapnia $\left(\mathrm{PaCO}_{2}>60 \mathrm{~mm} \mathrm{Hg}\right)$ results in increased $\mathrm{CBF}$ and decreased cerebral vascular resistance in newborn infants (4-6) and has been associated with intraventricular hemorrhage in some studies (7-9) but not in others $(10,11)$. There are some clinical data suggesting that hypercapnia may be harmful to the newborn brain even if it does not result in intraventricular hemorrhage (12-14). Moderate elevations in $\mathrm{PaCO}_{2}$ (end tidal $\mathrm{PCO}_{2}$ of $60 \mathrm{~mm} \mathrm{Hg}$ ) in healthy preterm (33-36 wk) infants significantly impeded brain stem auditory evoked responses (15). In other studies, very-low-birth-weight infants and term infants with impaired CBF reactivity during hypercapnia had poor neurologic outcomes or developed hypoxic ischemic encephalopathy $(16,17)$.

During hypercapnia, neuronal injury may result from alterations in cerebral blood flow, decreased extracellular and intracellular $\mathrm{pH}$, the generation of oxygen free radicals, and/or increased intracellular and intranuclear $\mathrm{Ca}^{++}$flux. In neurons, increased intracellular $\mathrm{Ca}^{++}$flux may be due to acidosis- 
induced activation of the cerebral NMDA receptor (18). Intracellular $\mathrm{Ca}^{++}$activates proteases, phospholipases, and nitric oxide synthase $(19,20)$. Activation of these enzymes may result in the generation of oxygen free radicals and in the peroxidation of nuclear membrane lipids and an increase in intranuclear $\mathrm{Ca}^{++}$-influx. Intranuclear $\mathrm{Ca}^{++}$forms a complex with calmodulin that initiates a signal cascade by activating various protein kinases including CaMK IV (21). Nuclear CaMK IV activates transcription factors including CREB by phosphorylating CREB at its active site $\mathrm{Ser}^{133}$, which then allows it to bind to DNA and results in the transcription of apoptotic genes (22), such as Bax. If elevated levels of Bax protein increase the ratio of proapoptotic to antiapoptotic (Bcl-2) proteins, cell death will be promoted. We propose that hypercapnia induces an increase in CaMK IV activity that may result in the subsequent phosphorylation of CREB protein and increased expression of Bax protein in the newborn brain.

To begin to examine the effects of normoxic hypercapnia on these early steps of transcription and apoptosis in the newborn brain, we studied anesthetized, ventilated newborn piglets exposed to two levels of increased arterial $\mathrm{PaCO}_{2}$ for $6 \mathrm{~h}$. In the present study, we tested the hypothesis that hypercapnia alters nuclear function in the newborn brain and specifically that hypercapnia results in a decrease in cerebral energy metabolism, activation of CaMK IV, phosphorylation of CREB, and increased expression of the proapoptotic protein Bax in the cerebral cortex of newborn piglets.

\section{METHODS}

Studies were performed in three groups of anesthetized, ventilated 1- to 3-d-old piglets, six normocapnic, seven with a $\mathrm{PaCO}_{2}$ of $65 \mathrm{~mm} \mathrm{Hg}$, and seven with a $\mathrm{PaCO}_{2}$ of $80 \mathrm{~mm} \mathrm{Hg}$. The experimental protocol was approved by the Institutional Animal Care and Use Committee of the Drexel University College of Medicine. Anesthesia was induced with $4 \%$ halothane and maintained with $0.8 \%$ halothane. Lidocaine $1 \%$ was injected locally for performance of a tracheostomy and insertion of aortic and inferior vena caval catheters. Intravenous fentanyl $(10 \mu \mathrm{g} / \mathrm{kg}$ initially and every hour) and tubocurarine $(0.3$ $\mathrm{mg} / \mathrm{kg}$ ) were given and the animals placed on a pressure ventilator using $75 \%$ nitrous oxide and $25 \%$ oxygen. Arterial blood $\mathrm{pH}, \mathrm{PaO}_{2}, \mathrm{PaCO}_{2}$, glucose, lactate, heart rate, and blood pressure were recorded at least every $15 \mathrm{~min}$ in all animals. Temperature was maintained with a warming blanket at $38-39^{\circ} \mathrm{C}$ rectal. After a 1-h period of stabilization, the piglets were divided into the following three groups: those ventilated for $6 \mathrm{~h}$ with a $\mathrm{PaCO}_{2} 40 \pm 2 \mathrm{~mm} \mathrm{Hg}$ and $\mathrm{PaO}_{2} 80-100 \mathrm{~mm} \mathrm{Hg}$ (normocapnic or $\mathrm{CO}_{2} 40$ group), those ventilated with $\mathrm{CO}_{2}$ added into the respiratory circuit to maintain a $\mathrm{PaCO}_{2}$ of approximately $65 \pm 2 \mathrm{~mm} \mathrm{Hg}$ and $\mathrm{PaO}_{2} 80-100 \mathrm{~mm} \mathrm{Hg}\left(\mathrm{CO}_{2} 65\right)$, and those ventilated with added $\mathrm{CO}_{2}$ to maintain a $\mathrm{PaCO}_{2}$ of approximately $80 \pm 2 \mathrm{~mm}$ $\mathrm{Hg}\left(\mathrm{CO}_{2} 80\right)$. Circuit $\mathrm{CO}_{2}$ values were monitored continuously in all animals. Piglets were maintained on D5 0.5 normal saline with calcium gluconate 100 $\mathrm{mg} / 100 \mathrm{~mL}$ at $100 \mathrm{~mL} / \mathrm{kg} / \mathrm{d}$. At the end of the experimental period, the brains were removed and within $4 \mathrm{~s}$ were placed either in buffer for the isolation of cell nuclei or in liquid nitrogen and stored at $-80^{\circ} \mathrm{C}$ for biochemical analysis.

Brain concentrations of ATP and PCr were determined by a coupled enzyme reaction as described by Lamprecht (23).

Cerebral cortical neuronal nuclei were isolated by homogenizing cortical tissue in 15 volumes of a medium containing $0.32 \mathrm{M}$ sucrose, $10 \mathrm{mM}$ Tris- $\mathrm{HCl}$ (pH 6.8), and $1 \mathrm{mM} \mathrm{MgCl}$, filtered through nylon cloth (mesh 100) and centrifuged at $850 \times g$ for $10 \mathrm{~min}$. The pellet was resuspended and mixed with a medium containing $2.4 \mathrm{M}$ sucrose, $10 \mathrm{mM}$ Tris- $\mathrm{HCl}(\mathrm{pH} 6.8)$, and $1 \mathrm{mM}$ $\mathrm{MgCl}_{2}$ to achieve a final concentration of $2.1 \mathrm{M}$ sucrose at which neuronal nuclei settle. The nuclear fraction was purified by centrifugation at $53,000 \times$ $g$ for $60 \mathrm{~min}$, a modification of the Guifrida et al. (24) method. The nuclear pellet was suspended in the medium $(0.32 \mathrm{M}$ sucrose, $10 \mathrm{mM}$ Tris- $\mathrm{HCl}$ buffer,
$\mathrm{pH} 6.8$, and $1 \mathrm{mM} \mathrm{MgCl}_{2}$ ) and the purity of neuronal nuclei was assessed by a phase contrast microscope (Olympus, Tokyo, Japan). The neuronal nuclei were characterized by the presence of a centrally located nucleolus (one nucleolus/nucleus) compared with the presence of multiple nucleoli in the astrocytic and oligodendrocytic nuclei. The final nuclear preparation was devoid of any microsomal, mitochondrial, or plasma membrane contaminant, with a purity for neuronal nuclei of $\geq 90 \%$ (25).

CaMK IV activity was determined as previously described (26) using $10 \mu \mathrm{L}$ of a $20 \mu \mathrm{cg} / 10 \mu \mathrm{L}$ preparation of neuronal nuclei for the reaction mixture by ${ }^{33} \mathrm{P}$ incorporation $\left(2 \mathrm{~min}\right.$ at $37^{\circ} \mathrm{C}$ ) into syntide- 2 in $25 \mu \mathrm{L}$ of a medium containing $50 \mathrm{mM}$ HEPES (pH 7.5), $2 \mu \mathrm{M}$ DTT, $40 \mu \mathrm{M}$ syntide- $2,10 \mathrm{mM} \mathrm{Mg}$ acetate, $5 \mu \mathrm{M}$ PKI 5-24 (protein kinase A inhibitor), $2 \mu \mathrm{M}$ PKC 19-36 (protein kinase $\mathrm{C}$ inhibitor), $1 \mu \mathrm{M}$ microcystin-LR (protein phosphatase $2 \mathrm{~A}$ inhibitor), $200 \mu \mathrm{M}$ sodium orthovanadate (inhibitor of ATPase, alkaline phosphatase, protein tyrosine phosphatase), $0.2 \mathrm{mM}$ ATP, $1 \mu \mathrm{Ci}{ }^{33} \mathrm{P}-\mathrm{ATP}$, and either $1 \mu \mathrm{M}$ calmodulin and $1 \mathrm{mM} \mathrm{CaCl}_{2}$ (for total activity) or $1 \mathrm{mM}$ EGTA (for $\mathrm{Ca}^{++} / \mathrm{CaM}$ independent activity). Twenty microliters of phosphorylated peptide medium was placed on phosphocellulose P81 membranes, washed, dried, and ${ }^{33} \mathrm{P}$ gamma labeled phosphorus and radioactivity counted. The difference in the presence and absence of $\mathrm{Ca}^{++} /$calmodulin was calculated and the enzyme activity was expressed as picomoles per milligram protein per minute.

CREB phosphorylation, Bax, and Bcl-2 protein density were determined through Western blotting techniques (27). Neuronal nuclear membranes were prepared as described above in the presence of protease inhibitors $(1 \mathrm{mM}$ phenylmethylsulfonyl fluoride, $10 \mathrm{~g} / \mathrm{mL}$ aprotinin, and $0.2 \mathrm{mM}$ sodium orthovanadate). Protein content was determined by the method of Lowry et al. (28), and the nuclear membrane preparation was diluted to a final concentration of $100 \mu \mathrm{g} / 100 \mu \mathrm{L}$. Five milliliters of Laemelli buffer were added to each 20 $\mu \mathrm{L}$ of nuclear membrane protein. Equal amounts of each neuronal nuclear protein $(35 \mu \mathrm{L}$ of the $100 \mu \mathrm{g} / 100 \mu \mathrm{L}$ preparation) were separated by $12 \%$ SDS-PAGE and transferred electrophoretically to nitrocellulose membranes. Nitrocellulose membranes in duplicate were then blocked with $8 \%$ nonfat milk in PBS. The membranes were subsequently incubated with anti-phosphorylated $\left(\operatorname{Ser}^{133}\right)$ CREB protein antibody (Upstate Biotechnology, Lake Placid, $\mathrm{NY}$ ) or with antibodies specific to Bax or Bcl-2 (Santa Cruz Biotechnology, Santa Cruz, CA). Recombinant human Bcl-2 BV-lysate (BD PharMingen, San Diego, CA) and human promyelocytic leukemia [ATCC (R) F-13737 240-CCL HL-60 018554, HL-60 promyelocytic leukemia human peripheral blood, Rockland, Gilbertsville, PA] served as positive controls for Bcl-2 and Bax proteins, respectively. Immunoreactivity was detected by incubation with horseradish peroxidase-conjugated secondary antibody (Rockland). Specific complexes were detected by enhanced chemiluminescence method using the ECL detection system (Amersham Pharmacia Biotech, Little Chalfont, Buckinghamshire, UK) and analyzed by imaging densitometry (GS-700 densitometer, Bio-Rad, Hercules, CA). The densitometric scanning data were expressed as autoradiographic values $\left(\mathrm{OD} \times \mathrm{mm}^{2}\right)$ per immunoblot protein representing CREB protein phosphorylation at $\mathrm{Ser}^{133}$, or Bax, or Bcl-2 protein density. In another set, CREB protein expression was also determined by anti-CREB antibody using the above method.

All data were reported as mean \pm SD. Physiologic data were analyzed using an area transformation of each piglet's data using SigmaPlot (Systat Software, Inc., Point Richmond, CA). After transformation, the data were averaged for the normocapnic and the hypercapnic groups. Statistical analysis between the three groups was performed by one-way ANOVA with subsequent Tukey tests for pair-wise comparisons of the mean responses of the different treatment groups. $p$ Values of $<0.05$ were considered statistically significant.

\section{RESULTS}

There was a significant decrease in arterial $\mathrm{pH}$ in both the $\mathrm{CO}_{2} 65(7.30 \pm 0.06)$ and the $\mathrm{CO}_{2} 80(7.25 \pm 0.01)$ groups compared with the $\mathrm{CO}_{2} 40$ group $(7.42 \pm 0.07)$ as demonstrated in Table 1. Although the $\mathrm{pH}$ was lower in the $\mathrm{CO}_{2} 80$ group than the $\mathrm{CO}_{2} 65$ group, there was not a statistically significant difference between the two groups. Arterial $\mathrm{PaCO}_{2}$ levels $\left(\mathrm{mm} \mathrm{Hg}\right.$ ) were significantly higher in the $\mathrm{CO}_{2} 80$ group $(81 \pm 4)$ than in the $\mathrm{CO}_{2} 65$ group $(68 \pm 1)$, and both were 
Table 1. Physiologic data of hypercapnic and normocapnic newborn piglets

\begin{tabular}{|c|c|c|c|c|c|}
\hline Groups & $\mathrm{pH}$ & $\begin{array}{c}\mathrm{PaCO}_{2} \\
(\mathrm{~mm} \mathrm{Hg})\end{array}$ & $\begin{array}{c}\mathrm{PaO}_{2} \\
(\mathrm{~mm} \mathrm{Hg})\end{array}$ & $\begin{array}{l}\text { Mean BP } \\
(\mathrm{mm} \mathrm{Hg})\end{array}$ & $\begin{array}{l}\text { Heart rate } \\
\text { (bpm) }\end{array}$ \\
\hline $\mathrm{PaCO}_{2} 40 \mathrm{~mm} \mathrm{Hg}$ & $7.42 \pm 0.07$ & $42 \pm 3$ & $103 \pm 15$ & $80 \pm 12$ & $194 \pm 44$ \\
\hline $\mathrm{PaCO}_{2} 65 \mathrm{~mm} \mathrm{Hg}$ & $7.30 \pm 0.06^{*}$ & $68 \pm 1 * *$ & $100 \pm 18$ & $76 \pm 10$ & $192 \pm 46$ \\
\hline $\mathrm{PaCO}_{2} 80 \mathrm{~mm} \mathrm{Hg}$ & $7.25 \pm 0.01^{*}$ & $81 \pm 4^{\S}$ & $103 \pm 26$ & $79 \pm 11$ & $202 \pm 38$ \\
\hline
\end{tabular}

Figures given as mean $\pm \mathrm{SD}$.

$* p<0.05$ vs $\mathrm{PaCO}_{2} 40 \mathrm{~mm} \mathrm{Hg}$.

** $p<0.05$ vs $\mathrm{PaCO}_{2} 40$ and $\mathrm{PaCO}_{2} 80 \mathrm{~mm} \mathrm{Hg}$.

${ }^{\S} p<0.05$ vs $\mathrm{PaCO}_{2} 40$ and $\mathrm{PaCO}_{2} 65 \mathrm{~mm} \mathrm{Hg}$.

higher than the $\mathrm{CO}_{2} 40$ group $(42 \pm 3)$. There was no difference in $\mathrm{PaO}_{2}$, mean blood pressure, or heart rate between the three groups as demonstrated in Table 1 .

ATP levels ( $\mu \mathrm{mol} / \mathrm{g}$ wet brain) were lower in the both the $\mathrm{CO}_{2} 65(3.85 \pm 0.41)$ and $80(4.0 \pm 0.14)$ groups than in the $\mathrm{CO}_{2} 40$ group $(4.65 \pm 0.27), p<0.05$ for both. Tissue $\mathrm{PCr}$ levels ( $\mu \mathrm{mol} / \mathrm{g}$ brain) were also lower in both the $\mathrm{CO}_{2} 65$ group (3.27 \pm 0.41$)$ and the $\mathrm{CO}_{2} 80$ group $(3.18 \pm 0.17)$ than in the $\mathrm{CO}_{2} 40$ group, $(3.85 \pm 0.20), p<0.05$ for both. Tissue levels of both ATP and PCr were not different between the $\mathrm{CO}_{2} 65$ and the $\mathrm{CO}_{2} 80$ groups.

CaMK IV activity (pmol/mg protein/min) as shown in Figure 1 was higher in the $\mathrm{CO}_{2} 65(1685 \pm 188)$ and the $\mathrm{CO}_{2} 80$ groups $(1529 \pm 198)$ than in the $\mathrm{CO}_{2} 40$ group $(1251 \pm 100)$ group. CaMK IV activity was not different between the $\mathrm{CO}_{2} 65$ and the $\mathrm{CO}_{2} 80$ groups.

There was an increase in density of phosphorylated CREB protein in both the $\mathrm{CO}_{2} 65$ and the $\mathrm{CO}_{2} 80$ groups compared with the $\mathrm{CO}_{2} 40$ group as demonstrated in Figure 2, a representative gel of phosphorylated CREB protein. The data show that the density (expressed as OD $\times \mathrm{mm}^{2}$ ) of phosphorylated CREB protein increased from $103 \pm 14$ in the $\mathrm{CO}_{2} 40$ group to $158 \pm 12$ in the $\mathrm{CO}_{2} 65$ group $(p<0.05)$ and $150 \pm 15$ in the $\mathrm{CO}_{2} 80$ group $\left(p<0.05\right.$ versus $\left.\mathrm{CO}_{2} 40\right)$. There was no difference in phosphorylated CREB density between the $\mathrm{CO}_{2}$ 65 and the $\mathrm{CO}_{2} 80$ groups. In another set of experiments,

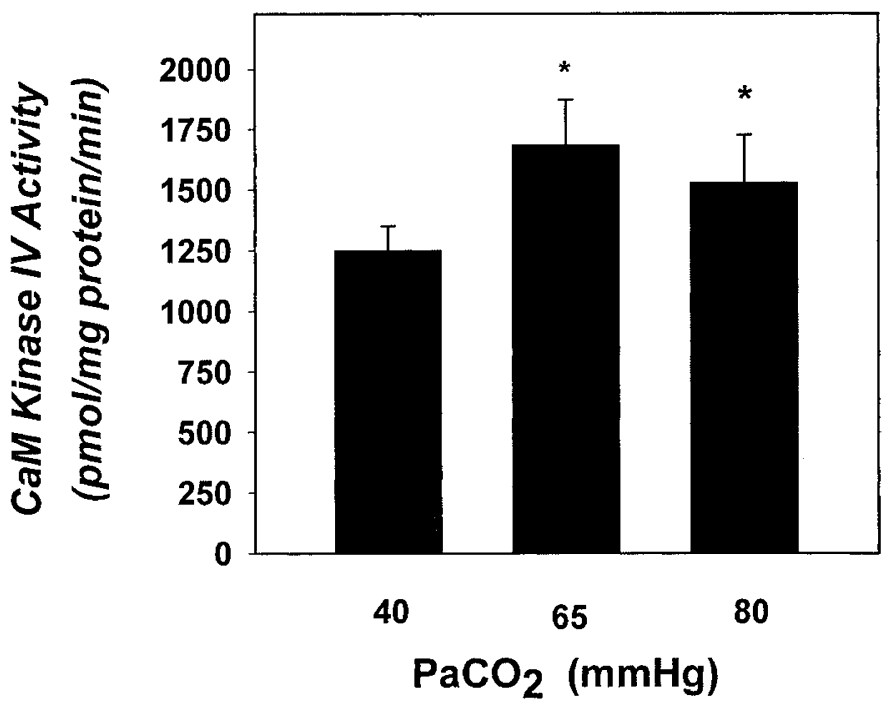

Figure 1. Neuron nuclear CaMK IV activity ( $\mathrm{pmol} / \mathrm{mg}$ protein/min) for the three groups, $\mathrm{CO}_{2} 40, \mathrm{CO}_{2} 65$, and $\mathrm{CO}_{2} 80$, in the cerebral cortex of newborn piglets. ${ }^{*} p<0.05$ vs $\mathrm{PaCO}_{2} 40 \mathrm{~mm} \mathrm{Hg}$.

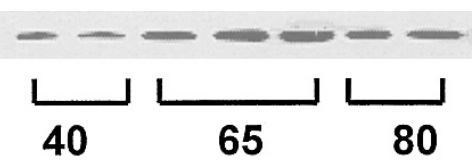

\section{$\mathrm{PaCO}_{2}(\mathrm{mmHg})$}

Figure 2. Representative Western blots of phosphorylated CREB Ser ${ }^{133}$ protein expression in $\mathrm{CO}_{2} 40, \mathrm{CO}_{2} 65$, and $\mathrm{CO}_{2} 80$ groups in neuronal nuclei of newborn piglets. The bands were visualized at a molecular weight of $43 \mathrm{kD}$.

CREB protein expression did not change in the $\mathrm{CO}_{2} 65$ or the $\mathrm{CO}_{2} 80$ group compared with the $\mathrm{CO}_{2} 40$ group.

Representative Western blots of $\mathrm{Bax}$ and $\mathrm{Bcl}-2$ protein expression in $\mathrm{CO}_{2} 40, \mathrm{CO}_{2} 65$, and $\mathrm{CO}_{2} 80$ piglets are shown in Figure 3, $a$ and $b$, respectively. Results demonstrate an increase in Bax protein density in the $\mathrm{CO}_{2} 65$ and $\mathrm{CO}_{2} 80$ groups compared with the $\mathrm{CO}_{2} 40$ group but no change in expression of Bcl-2 protein for the three groups. Bax protein expression $\left(\mathrm{OD} \times \mathrm{mm}^{2}\right)$ was significantly higher in the $\mathrm{CO}_{2} 65$ group (194 \pm 28$)$ and the $\mathrm{CO}_{2} 80$ group $(168 \pm 18)$ compared with the $\mathrm{CO}_{2} 40$ group $(95 \pm 12), p<0.05$ for both versus $\mathrm{CO}_{2}$ 40. There was no difference in Bax protein expression between the $\mathrm{CO}_{2} 65$ and $\mathrm{CO}_{2} 80$ groups. Bcl-2 protein $(\mathrm{OD} \times$ $\mathrm{mm}^{2}$ ) was similar in all three groups, $114 \pm 32$ in the $\mathrm{CO}_{2} 65$ group, $100 \pm 35$ in the $\mathrm{CO}_{2} 80$ group and $114 \pm 57$ in the $\mathrm{CO}_{2}$ 40 group. The ratio of $\mathrm{Bax} / \mathrm{Bcl}-2$ was higher in the $\mathrm{CO}_{2} 65$ $(1.83 \pm 0.66)$ and $\mathrm{CO}_{2} 80(1.86 \pm 0.75)$ groups than in the $\mathrm{CO}_{2} 40$ group $(0.91 \pm 0.18), p<0.05$ for both. There was no difference in the ratio of $\mathrm{Bax} / \mathrm{Bcl}-2$ protein in the $\mathrm{CO}_{2} 65$ and the $\mathrm{CO}_{2} 80$ groups.

\section{DISCUSSION}

In the present study, we have described the effects of two levels of elevated $\mathrm{PaCO}_{2}$ on the newborn brain, a $\mathrm{PaCO}_{2}$ of 65 a. Bax

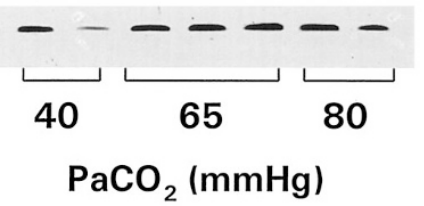

b. $B c /-2$

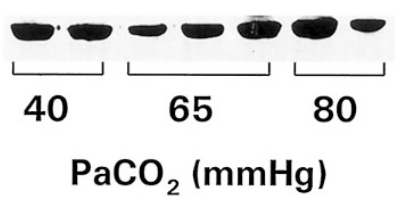

Figure 3. Representative Western blots of $\mathrm{Bax}(a)$ and Bcl-2 $(b)$ protein expression in neuronal nuclei of newborn piglets from the $\mathrm{CO}_{2} 40, \mathrm{CO}_{2} 65$, and $\mathrm{CO}_{2} 80$ groups. 
$\mathrm{mm} \mathrm{Hg}$ and $\mathrm{PaCO}_{2}$ of $80 \mathrm{~mm} \mathrm{Hg}$. The data demonstrate a decrease in high-energy phosphates, an increase in CaMK IV activity, an increase in phosphorylation of CREB protein, and increased Bax protein expression in piglets exposed to either a $\mathrm{PaCO}_{2}$ of $65 \mathrm{~mm} \mathrm{Hg}$ or a $\mathrm{PaCO}_{2}$ of $80 \mathrm{~mm} \mathrm{Hg}$ compared with the normocapnic piglets.

The results demonstrate that hypercapnia (either a $\mathrm{PaCO}_{2}$ of $65 \mathrm{~mm} \mathrm{Hg}$ or a $\mathrm{PaCO}_{2}$ of $80 \mathrm{~mm} \mathrm{Hg}$ ) resulted in an increase in nuclear CaMK IV activity. The increase in CaMK IV activity seen during hypercapnia may be due to hypercapnia-induced intracellular acidosis. The isoelectric point of CaMK IV is 4.65 (29), indicating that the enzyme will be fully charged in an acidotic environment. Indeed, activity of CaMK IV is increased during acidosis (30). In the carboxy region of the molecule, there is a stretch of amino acids of which $81 \%$ are glutamate residues including a string of 11 glutamate residues (31). During hypercapnia-induced acidosis, these glutamate residues may be fully ionized allowing maximal enzyme activity.

In neuronal nuclei, CaMK IV is the predominant form of CaM kinase (32) and results in the phosphorylation of CREB protein and $\mathrm{Ca}^{++}$-dependent gene transcription $(21,22)$. Transcription is activated only if CaMK IV is present (33). CaM kinases are activated by binding to a $\mathrm{Ca}^{++} /$calmodulin $\left(\mathrm{Ca}^{++} /\right.$ $\mathrm{CaM}$ ) complex, which induces a conformational change exposing the active site of the kinase previously blocked by the autoinhibitory domain $(21,34)$. The hypercapnia-induced increase in CaMK IV activity may result in the subsequent phosphorylation of CREB protein and increased expression of Bax protein in the newborn brain.

During both levels of hypercapnia there was an increase in phosphorylated CREB Ser ${ }^{133}$ protein density in the cerebral cortex of newborn piglets compared with normocapnic piglets. Activation of the cerebral NMDA receptor results in increased intracellular $\mathrm{Ca}^{++}$, which may potentiate $\mathrm{Ca}^{++}$flux into the nucleus and increase CaMK IV activity and CREB phosphorylation. Indeed, increased CREB $\operatorname{Ser}^{133}$ phosphorylation is dependent on intranuclear $\mathrm{Ca}^{++}$concentrations, and intracerebroventricular injection of NMDA potentiates binding of CREB protein to DNA in mice (35). In addition, both the phosphorylation and the activity of CaMK IV is increased by increasing intracellular $\mathrm{Ca}^{++}$flux through glutamate-induced NMDA receptor activation (36). We speculate that hypercapnia-induced acidosis results in alteration of the NMDA receptor and increases NMDA receptor-mediated intracellular $\mathrm{Ca}^{++}$ influx, leading to an increase in nuclear $\mathrm{Ca}^{++}$influx and phosphorylation of CREB protein in newborn piglets.

Phosphorylation of CREB protein results in gene transcription (37). CREB is a member of the leucine-zipper class of proteins. These proteins can form homodimers and heterodimers that bind to a regulatory DNA sequence known as the cAMP-responsive element (CRE) (37), resulting in the transcription of genes containing CRE sequences (38). The binding of CREB to CRE does not induce transcription unless phosphorylation of CREB at $\operatorname{Ser}^{133}$ has occurred (39). When CREB protein is phosphorylated, there is an increase in the spherical site and net-positive surface charge of the CREB/ DNA complex. Therefore, it appears that phosphorylation of
CREB protein alters its binding affinity, its secondary structure, and the charge characteristics of the molecule (40), all of which may be enhanced in an acidotic environment.

The study shows that during hypercapnia there was an increase in expression of Bax protein resulting in an increased ratio of the proapoptotic protein Bax to the anti-apoptotic protein $\mathrm{Bcl}-2$ compared with normocapnic piglets. Both Bax and $\mathrm{Bcl}-2$ proteins are expressed in neurons of the central and peripheral nervous system during brain development $(41,42)$ and are critical regulators of programmed cell death. Bcl-2 protein is antiapoptotic, enhancing cell survival possibly through regulating cytosolic and intranuclear $\mathrm{Ca}^{++}$concentrations (43). In contrast, the proapoptotic protein Bax has been shown to promote cell death by activating caspases, especially caspase-3 $(44,45)$. The active form of Bcl-2 heterodimerizes with Bax and their ratio determines the cellular susceptibility to apoptotic stimuli $(46,47)$. During hypercapnia, the increase in Bax protein and ratio of $\mathrm{Bax} / \mathrm{Bcl}-2$ indicates a propensity of the cells to undergo programmed cell death in the newborn piglet brain.

In addition to Bax, hypercapnia has been shown to induce the expression of other nuclear proteins as well. The nuclear protein FOS is expressed in brainstem chemosensitive neurons (48) during hypercapnia. FOS expression appears to be mediated by activation of MAP kinases, PKC $\alpha$ and PKC $\beta$ (49). Therefore, it appears that hypercapnia leads to the activation of kinases and the subsequent expression of neuronal apoptotic proteins.

We have postulated that during hypercapnia the ensuing respiratory acidosis alters brain cell membranes and results in increased CaMK IV activity, phosphorylation of CREB protein, and Bax protein expression in the cerebral cortex of newborn piglets.

During hypercapnia, there is a decrease in extracellular and intracellular $\mathrm{pH}$ (50-52). The hypercapnia-induced intracellular acidosis has been shown to retard oxidative phosphorylation. Nuclear magnetic resonance studies during hypercapnia demonstrated that there was a linear correlation between inorganic phosphate $(\mathrm{Pi})$ /nucleotide triphosphates (NTP) and brain $\mathrm{pH}_{\mathrm{i}}$ (53). During hypercapnia $\left(\mathrm{PaCO}_{2} 98 \pm 3 \mathrm{~mm} \mathrm{Hg}\right)$ in newborn lambs, there was a significant increase in the ratio of Pi to NTP and a significant decrease in the ratio of PCr to Pi. We have also demonstrated the impact of hypercapnia on cellular metabolism with the hypercapnia-induced decrease in high-energy phosphates. We anticipate that the decrease in tissue levels of ATP and PCr in our newborn piglets was due to the increased metabolic demand on the neurons to maintain ionic homeostasis during acidosis.

In tissue slices (54) and cultured astrocytes (55), a reduction in $\mathrm{pH}_{\mathrm{e}}$ leads to brain edema and cell necrosis (56). During hypercapnia, when both $\mathrm{pH}_{\mathrm{i}}$ and $\mathrm{pH}_{\mathrm{e}}$ are lowered, restitution of normal $\mathrm{pH}_{\mathrm{i}}$ may not be feasible resulting in neuronal injury and possibly cell death through activation of nuclear transcription mechanisms. It has been suggested that the hypercapniainduced increase in intracellular $\left[\mathrm{H}^{+}\right]$may compete for binding sites with intracellular $\mathrm{Ca}^{++}$, resulting in an increase in free cytosolic $\mathrm{Ca}^{++}$(57). We propose that a hypercapnia-induced increase in intracytosolic $\mathrm{Ca}^{++}$results in an increase in in- 
tranuclear $\mathrm{Ca}^{++}$-influx as membrane enzymes are altered by acidosis. The increase in intranuclear $\mathrm{Ca}^{++}$then may activate CaMK IV, phosphorylation of CREB, and the transcription of apoptotic genes as demonstrated in our current study.

The two groups of piglets, the $\mathrm{CO}_{2} 65$ and $\mathrm{CO}_{2} 80$ groups, had a similar decrease in high-energy phosphates, increased CaMK IV activity, increased phosphorylation of CREB protein, and increased expression of Bax protein. However, even though these groups had statistically different levels of $\mathrm{PaCO}_{2}$, the $\mathrm{pH}$ range for each group was not statistically different. We anticipate that the effects of hypercapnia on the brain are due to decreases in $\mathrm{pH}$, and not due to differences in $\mathrm{PaCO}_{2}$.

\section{CONCLUSION}

We conclude that $6 \mathrm{~h}$ of either a $\mathrm{PaCO}_{2}$ of $65 \mathrm{~mm} \mathrm{Hg}$ or $80 \mathrm{~mm}$ $\mathrm{Hg}$ alters nuclear enzyme activity and protein expression in the cerebral cortex of newborn piglets. Specifically, hypercapnia results in a decrease in cerebral energy metabolism, an increase in CaMK IV activity, phosphorylation of CREB protein, and the expression of apoptotic proteins. We propose that the acidosis induced by hypercapnia may be deleterious to the newborn brain and alters nuclear membrane enzymes leading to an increase in intranuclear $\mathrm{Ca}^{++}$that results in an increase in CaMK IV activity, the subsequent expression of apoptotic genes, and cell death in the cerebral cortex of the newborn piglet.

Acknowledgments. The authors thank Anli Zhu and Sijian Wu for their expert technical advice.

\section{REFERENCES}

1. Woodgate PG, Davies MW 2001 Permissive hypercapnia for the prevention of morbidity and mortality in mechanically ventilated newborn infants. Cochrane Database Syst Rev CD 002061

2. Varughese M, Patole S, Shama A, Whitehall J 2002 Permissive hypercapnia in neonates: the case of the good, the bad, and the ugly. Pediatr Pulmonol 33:56-64

3. Mariani G, Cifuentes J, Carlo WA 1999 Randomized trial of permissive hypercapnia in preterm infants. Pediatrics 104:1082-1088

4. Wyatt JS, Edwards AD, Cope M, Delpy DT, McCormick DC, Potter A, Reynolds EO 1991 Response of cerebral blood volume to changes in arterial carbon dioxide tension in preterm and term infants. Pediatr Res 29:553-557

5. Leahy FA, Cates D, MacCallum M, Rigatto $\mathrm{H} 1980$ Effect of $\mathrm{CO}_{2}$ and $100 \% \mathrm{O}_{2}$ on cerebral blood flow in preterm infants. J Appl Physiol 48:468-472

6. van Bel F, van de Bor M, Baan J, Ruys JH 1988 The influence of abnormal blood gases on cerebral blood flow velocity in the preterm newborn. Neuropediatrics 19:27-32

7. Wallin LA, Rosenfeld CR, Laptook AR, Maravilla AM, Strand C, Campbell N, Dowling S, Lasky RE 1990 Neonatal intracranial hemorrhage: II. Risk factor analysis in an inborn population. Early Hum Dev 23:129-137

8. Ment LR, Oh W, Philip AG, Ehrenkranz RA, Duncan CC, Allan W, Taylor KJ, Schneider K, Katz KH, Makuch RW 1992 Risk factors for early intraventricular hemorrhage in low birth weight infants. J Pediatr 121:776-783

9. Szymonowicz W, Yu VY, Wilson FE 1984 Antecedents of periventricular haemorrhage in infants weighing $1250 \mathrm{~g}$ or less at birth. Arch Dis Child 59:13-17

10. Levene MI, Fawer CL, Lamont RF 1982 Risk factors in the development of intraventricular haemorrhage in the preterm neonate. Arch Dis Child 57:410-417

11. Skouteli HN, Kuban KC, Leviton A, Brown ER, Krishnamoorthy KS, Pagano M, Allred EN, Sullivan KF, Baglivo JA, Huff KR 1988 Arterial blood gas derangements associated with death and intracranial hemorrhage in premature babies. J Perinatol 8:336-341

12. Volpe JJ 2000 Neurology of the Newborn. W.B. Saunders, Philadelphia

13. Ment LR, Oh W, Philip AG, Ehrenkranz RA, Duncan CC, Allan W, Taylor KJ, Schneider K, Katz KH, Makuch RW 1992 Risk factors for early intraventricula hemorrhage in low birth weight infants. J Pediatr 121:776-783

14. Szymonowicz W, Yu VY, Wilson FE 1984 Antecedents of periventricular haemorrhage in infants weighing $1250 \mathrm{~g}$ or less at birth. Arch Dis Child 59:13-17

15. Friss HE, Wavrek D, Martin WH, Wolfson MR 1994 Brain-stem auditory evoked responses to hypercarbia in preterm infants. Electroencephalogr Clin Neurophysiol 90:331-336

16. Muller AM, Morales C, Briner J, Baenziger O, Duc G, Bucher HU 1997 Loss of CO reactivity of cerebral blood flow is associated with severe brain damage in mechanically ventilated very low birth weight infants. Eur J Paediatr Neurol 1:157-163
17. Pryds O, Greisen G, Lou H, Friis-Hansen B 1990 Vasoparalysis associated with brain damage in asphyxiated term infants. J Pediatr 119-125

18. Zanelli SA, Numagami Y, McGowan JE, Mishra OP, Delivoria-Papadopoulos M 1999 NMDA receptor-mediated calcium influx on cerebral cortical synaptosomes of the hypoxic guinea pig fetus. Neurochem Res 24:437-446

19. Halliwell B 1999 Antioxidant defense mechanisms: from the beginning to the end (of the beginning). Free Radic Res 31:261-272

20. Mishra OP, Delivoria-Papadopoulos M 1999 Cellular mechanisms of hypoxic injury in the developing brain. Brain Res Bull 48:233-238

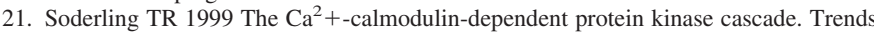
Biochem Sci 24:232-236

22. Enslen H, Sun P, Brickley D, Soderling SH, Klamo E, Soderling TR 1994 Characterization of $\mathrm{Ca}^{2+} /$ calmodulin-dependent protein kinase IV. Role in transcriptional regulation. J Biol Chem 269:15520-15527

23. Lamprecht W 1974 Creatine phosphate. In: Bergmeyer HU (ed) Methods of Enzymatic Analysis. Academic Press, New York, pp 1777-1781

24. Guifrida AM, Cox D, Mathias AP 1975 RNA polymerade activity in various classes of nuclei from different regions of rat brain during postnatal development. J Neurochem 24:749-755

25. Austoker J, Cox D, Mathias AP 1972 Fractionation of nuclei from brain zonal centrifugation and a study of the ribonucleic acid polymerase activity in the various classes of nuclei. Biochem J 129:1139-1155

26. Park IK, Soderling TR 1995 Activation of $\mathrm{Ca} 2+/$ calmodulin-dependent protein kinase (CaM-kinase) IV by CaM-kinase kinase in Jurkat T lymphocytes. J Biol Chem 270:30464-30469

27. Mishra OP, Ashraf QM, Delivoria-Papadopoulos M 2002 Phosphorylation of cAMP response element binding (CREB) protein during hypoxia in cerebral cortex of newborn piglets and the effect of nitric oxide synthase inhibition. Neuroscience 115:985-991

28. Lowry OH, Rosenbrough NJ, Farr AL, Randall RJ 1951 Protein measurement with the Folin phenol reagent. J Biol Chem 193:265-275

29. Jones DA, Glod J, Wilson-Shaw D, Hahn WE, Sikela JM 1991 cDNA sequence an differential expression of the mouse $\mathrm{Ca} 2+/$ calmodulin-dependent protein kinase IV gene. FEBS Lett 289:105-109

30. Miyano O, Kameshita I, Fujisawa H 1992 Purification and characterization of a brain-specific multifunctional calmodulin-dependent protein kinase from rat cerebellum. J Biol Chem 267:1198-1203

31. Ohmstede CA, Jensen KF, Sahyoun NE 1989 Ca2+/calmodulin-dependent protein kinase enriched in cerebellar granule cells. Identification of a novel neuronal calmodulin-dependent protein kinase. J Biol Chem 264:5866-5875

32. Sheng M, Thompson MA, Greenberg ME 1991 CREB: a Ca(2+)-regulated transcription factor phosphorylated by calmodulin-dependent kinases. Science 252:1427-1430

33. Chawla S, Hardingham GE, Quinn DR, Bading H 1998 CBP: a signal-regulated transcriptional coactivator controlled by nuclear calcium and CaM kinase IV. Science 281:1505-1509

34. Tokumitsu H, Soderling TR 1996 Requirements for calcium and calmodulin in the calmodulin kinase activation cascade. J Biol Chem 271:5617-5622

35. Ogita K, Yoneda Y 1994 Selective potentiation of DNA binding activities of both activator protein 1 and cyclic AMP response element binding protein through in vivo activation of $\mathrm{N}$-methyl-D-aspartate receptor complex in mouse brain. J Neurochem 63:525-534

36. Kasahara J, Fukunaga K, Miyamoto E 2000 Activation of $\mathrm{CA}(2+) /$ calmodulin dependent protein kinase IV in cultured rat hippocampal neurons. J Neurosci Res 59:594-600

37. Andrisani OM 1999 CREB-mediated transcriptional control. Crit Rev Eukaryot Gene Expr 9:19-32

38. Moore AN, Waxham MN, Dash PK 1996 Neuronal activity increases the phosphorylation of the transcription factor cAMP response element-binding protein (CREB) in rat hippocampus and cortex. J Biol Chem 271:14214-14220

39. Hagiwara M, Shimomura A, Yoshida K, Imaki J 1996 Gene expression and CREB phosphorylation induced by cAMP and $\mathrm{Ca} 2+$ in neuronal cells. Adv Pharmacol 36:277-285

40. Bullock BP, Habener JF 1998 Phosphorylation of the cAMP response element binding protein CREB by cAMP-dependent protein kinase A and glycogen synthase kinase-3 alters DNA-binding affinity, conformation, and increases net charge. Biochemistry 37:3795-3809

41. Chen J, Graham SH, Chan PH, Lan J, Zhou RL, Simon RP 1995 bcl-2 is expressed in neurons that survive focal ischemia in the rat. Neuroreport 6:394-398

42. Merry DE, Veis DJ, Hickey WF, Korsmeyer SJ 1994 Bcl-2 protein expression is widespread in the developing nervous system and retained in the adult PNS. Development 120:301-311

43. Marin MC, Fernandez A, Bick RJ, Brisbay S, Buja LM, Snuggs M, McConkey DJ, von Eschenbach AC, Keating MJ, McDonnell TJ 1996 Apoptosis suppression by $\mathrm{Bcl}-2$ is correlated with regulation of nuclear and cytosolic $\mathrm{Ca}_{2}^{+}$. Oncogene 12:2259-2266

44. Chinnaiyan AM, O'Rourke K, Lane BR, Dixit VM 1997 Interaction of CED-4 with CED-3 and CED-9: a molecular framework for cell death. Science 275:1122-1126

45. Thornberry NA, Lazebnik Y 1998 Caspases: enemies within. Science 281:1312-1316

46. Gillardon F, Wickert H, Zimmermann M 1995 Up-regulation of bax and downregulation of bcl-2 is associated with kainate-induced apoptosis in mouse brain. Neurosci Lett $192 \cdot 85-88$

47. Oltvai ZN, Milliman CL, Korsmeyer SJ 1993 Bcl-2 heterodimerizes in vivo with a conserved homolog, Bax, that accelerates programmed cell death. Cell 74:609-619

48. Haxhiu MA, Yung K, Erokwu B, Cherniack NS 1996 CO $_{2}$-induced c-fos expression in the CNS catecholaminergic neurons. Respir Physiol 105:35-45 
49. Kuo NT, Agani FH, Haxhiu MA, Chang CH 1998 A possible role for protein kinase C in $\mathrm{CO}_{2} / \mathrm{H}+$-induced c-fos mRNA expression in $\mathrm{PC} 12$ cells. Respir Physiol 111:127-135

50. Wagerle LC, Mishra OP 1988 Mechanism of $\mathrm{CO}_{2}$ response in cerebral arteries of the newborn pig: role of phospholipase, cyclooxygenase, and lipoxygenase pathways. Circ Res 62:1019-1026

51. Cady EB, Chu A, Costello AM, Delpy DT, Gardiner RM, Hope PL, Reynolds EO 1987 Brain intracellular $\mathrm{pH}$ and metabolism during hypercapnia and hypocapnia in the new-born lamb. J Physiol 382:1-14

52. Rosenberg AA, Jones MD Jr, Traystman RJ, Simmons MA, Molteni RA 1982 Response of cerebral blood flow to changes in $\mathrm{PCO}_{2}$ in fetal, newborn, and adult sheep. Am J Physiol 242:H862-H866
53. Cady EB, Chu A, Costello AM, Delpy DT, Gardiner RM, Hope PL, Reynolds EO 1987 Brain intracellular $\mathrm{pH}$ and metabolism during hypercapnia and hypocapnia in the new-born lamb. J Physiol 382:1-14

54. Patel KK, Hartmann JF, Cohen MM 1973 Effect of pH on metabolism and ultrastructure of guinea pig cerebral cortex slices. Stroke 4:221-231

55. Goldman SA, Pulsinelli WA, Clarke WY, Kraig RP, Plum F 1989 The effects of extracellular acidosis on neurons and glia in vitro. J Cereb Blood Flow Metab 9:471-477

56. MacGregor DG, Chesler M, Rice ME 2001 HEPES prevents edema in rat brain slices. Neurosci Lett 303:141-144

57. Siesjo BK, Katsura K, Mellergard P, Ekholm A, Lundgren J, Smith ML 1993 Acidosis-related brain damage. Prog Brain Res 96:23-48 